\title{
Alcohol Dehydrogenase from Sheep Liver: Purification, Characterization and Impacts of Some Antibiotics
}

\author{
Yeliz DEMIR ${ }^{2}$, Bülent ŞENGÜL ${ }^{3}$, Bülent ERGUN ${ }^{1}$, Şükrü BEYDEMIR ${ }^{1}$
}

\begin{abstract}
Alcohol dehydrogenase (ADH) is a dimeric enzyme in which each subunit of the enzyme has a $\mathrm{Zn}^{2+}$ metal-containing catalytic domain and a cofactor-binding domain. This enzyme converts the alcohol to aldehyde. The present article focuses on the purification, characterization and in vitro effects of some antibiotics on alcohol dehydrogenase from sheep liver. ADH was purified with specific activity of $0.5 \mathrm{U} / \mathrm{mg}$ proteins and approximately 52.03-fold from sheep liver by DEAE-Sephadex A-50 ion exchange chromatography and gel filtration on Sephadex G-100. The subunit and the natural molecular weights of the enzyme were determined by gel filtration and SDSPAGE 80.49 and $38.16 \mathrm{kDa}$, respectively. The optimum ionic strenght, temperature and, $\mathrm{pH}$ of ADH was $400 \mathrm{mM}$, $40^{\circ} \mathrm{C}$ and, 10.5 , respectively. The inhibitory effects of the antibiotics were tested at various concentrations. $\mathrm{IC}_{50}$ values for kanamycin sulfate, amikacin sulfate, gentamicin, lincomycin, and clindamycin were found to be 43.31 , $36.47,20.38,18.73$ and $1.31 \mathrm{mM}$, respectively.
\end{abstract}

Keywords: Alcohol dehydrogenase, antibiotics, characterization, inhibition, purification

\section{Koyun Karaciğerinden Alkol Dehidrogenaz: Saflaştırma, Karakterizasyon, ve Bazı Antibiyotiklerin Etkileri}

ÖZET: Alkol dehidrogenaz (ADH), enzimin her bir alt biriminin bir $\mathrm{Zn}^{2+}$ metal içeren katalitik alana ve bir kofaktör bağlama alanına sahip olduğu dimerik bir enzimdir. Bu enzim, alkolü, aldehide dönüştürür. Bu makale koyun karaciğerinden alkol dehidrogenazın saflaştırılması, karakterizasyonu enzimin aktivitesi üzerine bazı antibiyotiklerin in vitro ekilerine odaklanmaktadır. ADH, DEAE-Sephadex A-50 iyon değişim kromatografisi ve Sephadex G-100 jel filtrasyon kromatografisi vasitasıyla koyun karaciğerinden $0.5 \mathrm{U} \mathrm{mg}^{-1}$ protein spesifik aktivite ve yaklaşık olarak 52.03-kat saflaştırıldı. Enzimin alt birim ve doğal hallerinin molekül kütleleri jel filtrasyon kromatografisi and SDS-PAGE ile sırasıyla 80.49 and $38.16 \mathrm{kDa}$ olarak belirlendi. ADH'ın optimum iyonik şiddeti, sıcaklığı ve pH'sı sırasıyla $400 \mathrm{mM}, 40^{\circ} \mathrm{C}$ and, 10.5 idi. Antibiyotiklerin inhibitor etkileri çeşitli konsantrasyonlarda denendi. Kanamisin sülfat, amikasin sulfat, gentamisin, lincomisin, and klindamisin için $\mathrm{IC}_{50}$ değerleri sırasıyla, $43.31,36.47,20.38,18.73$ ve $1.31 \mathrm{mM}$ olarak bulundu.

Anahtar Kelimeler: Alkol dehidrogenaz, antibiotikler, inhibisyon, karakterizasyon, saflaştırma

\footnotetext{
Anadolu Üniversitesi, Eczacılık Fakültesi, Biyokimya, Eskişehir, Türkiye

Atatürk Üniversitesi, Fen Fakültesi, Kimya, Erzurum, Türkiye

Bayburt Üniversitesi, Sağlık Hizmetleri Meslek Yüksekokulu, Sağlık Hizmetleri Bölümü , Bayburt, Türkiye

Sorumlu yazar/Corresponding Author: Şükrü BEYDEMIR, sukrubeydemir@anadolu.edu.tr
} 


\section{INTRODUCTION}

It is well known that long-term and excessive alcohol consumption causes many various diseases including liver disorders. Some of these can be irreversible and fatal for human life. Particularly, liver is a unique member called as mother of body. Any disorder in the liver affects to the all body functions. Therefore, many studies have been carried out on liver alcohol metabolism for a long time ( $\mathrm{Li}$ and Ding, 2017; Stickel, et al., 2017)
Alcohol metabolism contains mainly two pathways, oxidative and non-oxidative pathways. The oxidative pathway takes place in the liver and another in extrahepatic tissues. Oxidative reaction is a catalyzed major pathway by cytosolic alcohol dehydrogenase enzyme. Alcohol dehydrogenase (ADH, EC 1.1.1.1) is a crucial enzyme in this pathway. The zinc containing enzyme is responsible for the reversible oxidation of alcohol to aldehyde, a highly toxic molecule, by the reduction of $\mathrm{NAD}^{+}$to NADH.

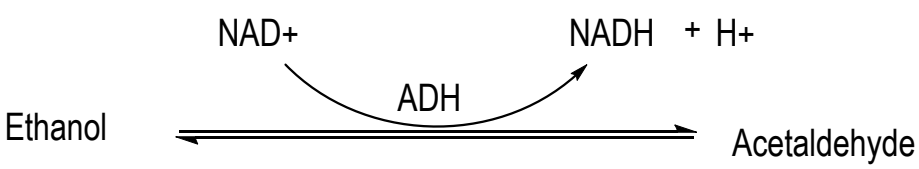

The active form of ADH is generally at dimeric form in the liver (Sunderland et al., 2016) In the present study, ADH was obtained from sheep liver by some chromatographic techniques. The inhibitory effects of the antibiotics on $\mathrm{ADH}$ were investigated at various concentrations. These results may be important in terms of alcohol consumption when using these drugs in case of illness. It is known that the reaction catalyzed by $\mathrm{ADH}$ is the main way of alcohol detoxification. Thus, inhibition of the enzyme may cause some vital side effects. On the other hand, to understand that the enzyme is a target for some drugs may provide an important advantage about steps to be followed in treatment.

Accumulation of acetaldehyde increases with ADH inhibition or excessive consumption of the ethanol. These nasty symptoms are characterized as thirst, vomiting, dizziness headache and other decreased sensory abilities (Manir, M.M., et al., 2012). Already, it is well known that the intermediate acetaldehyde may be carcinogenic, mutagenic and toxic. Actually, the reaction of ethanol conversion to acetaldehyde is thought to be a suitable way of preventing alcoholic disorders. However, inhibition of ADH or accumulation of acetaldehyde can cause negative effects as mentioned above (Figure 1).

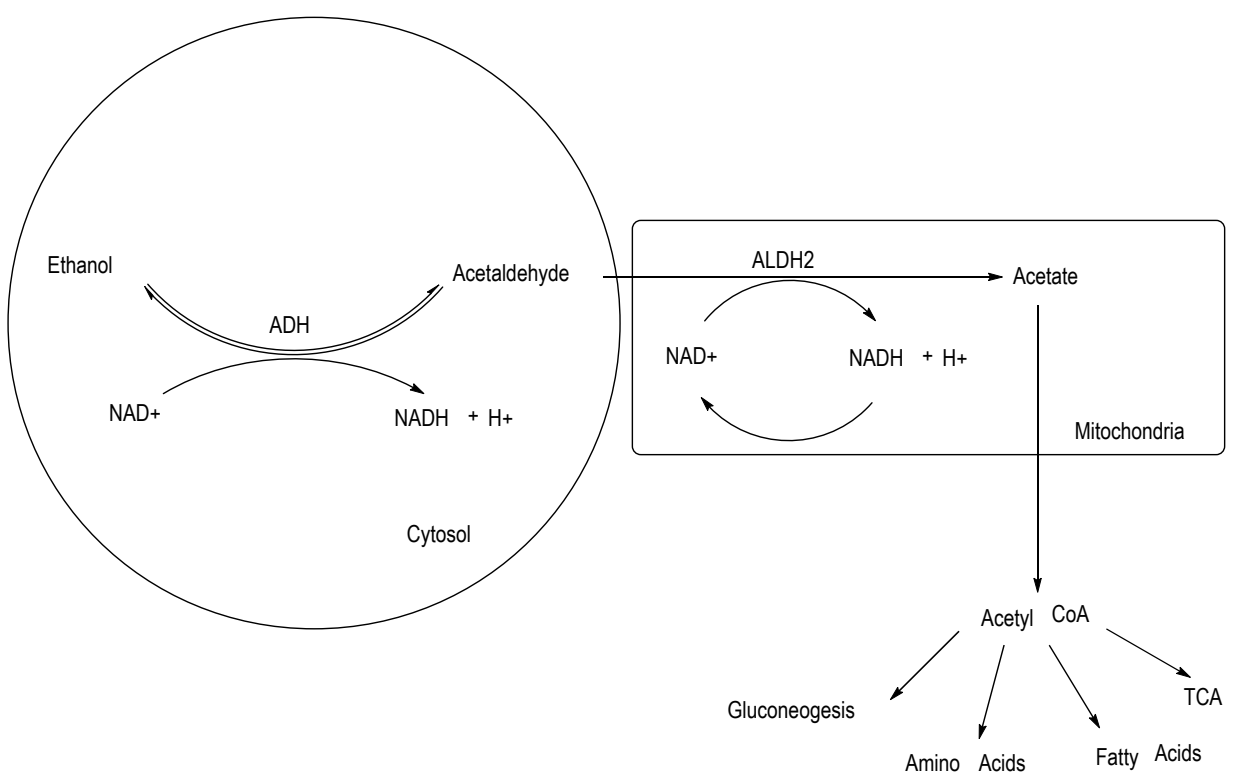

Figure 1. The reaction is a catalyzed major pathway by cytosolic alcohol dehydrogenase enzyme. Alcohol dehydrogenase is a crucial enzyme in this pathway. Accumulation of acetaldehyde increases with ADH inhibition or excessive consumption of the ethanol. it is well known that the intermediate acetaldehyde may be carcinogenic, mutagenic and toxic. Actually, the reaction of ethanol conversion to acetaldehyde is thought to be a suitable way of preventing alcoholic disorders. However, inhibition of ADH or accumulation of acetaldehyde can cause negative effects as mentioned above. 
Enzyme inhibition can be caused by a number of substances such as chemicals, pesticides, herbicides including drug molecules. Thus, the rate of an enzyme activity may be either completely dropped or stopped. Almost all substances display their toxic effects in a similar way. Particularly, some enzymes are called as drug-target such as carbonic anhydrase, paraoxonase and sorbitol dehydrogenase (Mert et al., 2016; Alım and Beydemir 2016; Aslan And Beydemir, 2017). Antibiotics are indispensable drugs especially for the treatment of bacterial infections. Antibiotics in different classes are known to be effective on different bacteria. The selected drugs for this study, gentamycin, kanamycin and amikacin are in aminoglycosides and lincomycin, clindamycin are also in a group of lincosamides (Figure 2). Aminoglycosides are a class of antibiotics having a strong activity against most gram-negative bacteria and they are commonly used in antimicrobial therapy. Gentamicin is employed for the

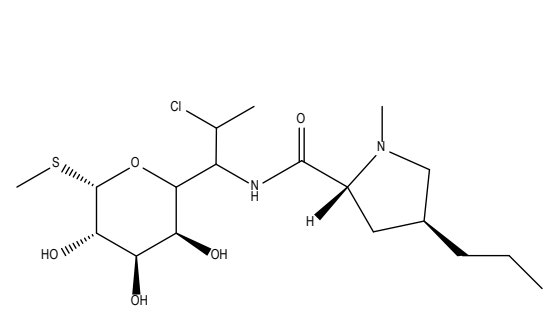

Clindamycin

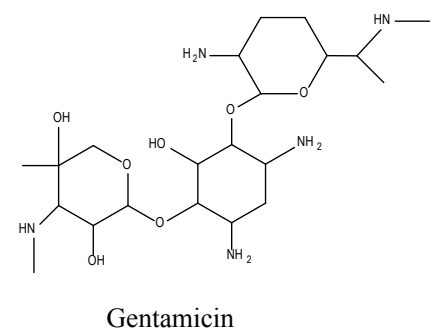

treatment of crucial infections caused by gram negative bacteria (Lin, L., et al., 2011). Kanamycin produced by Streptomyces kanamyceticus is used to treat gram-negative and gram-positives bacterial infections. This drug has a role in inhibition and reduction of translation fidelity and bacterial protein synthesis at ribosomal level (Kotra et al., 2000). Amikacin is the broadest spectrum aminoglycoside with the least resistance. Also, amikacin is a frequently preferred agent owing to its favorable features including fast and potent bactericidal effect, synergy with $\beta$-lactam antibiotics, low resistance, chemical stability and lower cost (Kent, A., et al., 2014). Lincomycin, a member of lincosamide antibiotics, was discovered from the fermentation of Streptomyces spp. in 1963 (Giguère, 2013). This drug is effective against gram positive and anaerobic bacteria. Clindamycin, a lincomycin analog, shows distinct advantages over lincomycin for the treatment of a number of bacterial infections (Batzias et al., 2005).

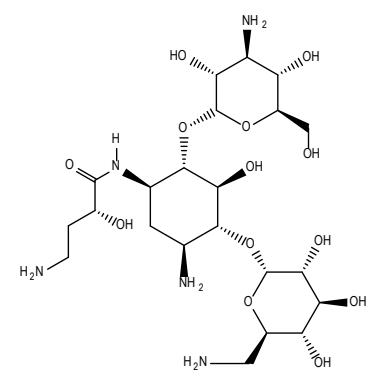

Amikacin<smiles>NCC1OC(OC2C(N)CC(N)C(OC3OC(CO)C(O)C(N)C3O)C2O)C(O)C(O)C1O</smiles>

Kanamycin

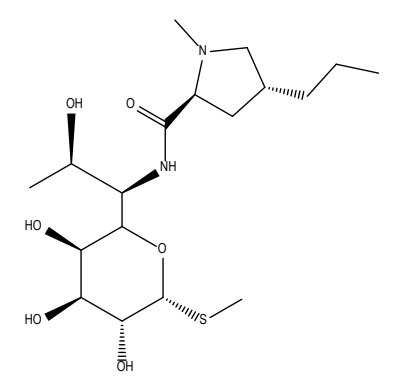

Lincomycin

Figure 2. Chemicals structures of antibiotics used for in vitro inhibition studies on ADH activity are kanamycin sulfate, amikacin sulfate, gentamicin, lincomycin, and clindamycin 
Consequently, the reaction catalyzed by alcohol dehydrogenase is important point for both biosynthesis and energy metabolism. Because, produced acetaldehyde and then acetate serve as a major contributor for Acetyl CoA molecule. Therefore, investigation of interaction of this enzyme with drugs may be important in terms of to develop a treatment method for some patients.

\section{MATERIAL AND METHODS}

\section{Chemicals}

DEAE Sephadex A-50, Sephadex G-100, NAD ${ }^{+}$, protein assay reagents and chemicals for electrophoresis were obtained from Sigma-Aldrich Co. All other chemicals were analytical grade and obtained from Merck.

\section{Purification of alcohol dehydrogenase from sheep liver}

ADH was purified from sheep liver by using simple chromatographic methods such as ammonium sulfate fractionation DEAE-Sephadex anion exchange chromatography and Sephadex G-100 gel filtration chromatography. These techniques had been explained in our previous studies (Ekinci and Beydemir, 2009; İşgör and Beydemir, 2010; Türkeş et al., 2016) The first purification step was ammonium sulfate precipitation. Solid ammonium sulfate was added by gently mixing serum sample at $0 \%-60 \%$ and $60 \%-80 \%$ saturations. After mixing, the bulk was centrifuged at $24000 \times \mathrm{g}$ for $30 \mathrm{~min}$ at $4^{\circ} \mathrm{C}$. The protein pellet from $60 \%$ to $80 \%$ ammonium sulfate saturation was dissolved in $10 \mathrm{mM}$ Na-phosphate buffer ( $\mathrm{pH} \mathrm{8.0)}$ and dialyzed against the same buffer. The dialyzed enzyme solution was loaded onto the DEAE-Sephadex A-50 anion exchange column previously equilibrated with $10 \mathrm{mM}$ Na-phosphate buffer ( $\mathrm{pH}$ 8.0). Twelve $\mathrm{ml}$ of concentrated enzyme was loaded to the top of the column. The enzyme was eluted with linear gradient of $0.2-1.5 \mathrm{M} \mathrm{NaCl}$ at a flow rate of about $30 \mathrm{ml} / \mathrm{h}$ using a peristaltic pump (Ismatec) and fractions of $3.0 \mathrm{ml}$ were collected and the enzyme activity was analysed at $340 \mathrm{~nm}$, spectrophotometrically. The fractions with the enzyme activity were pooled and mixed with glycerol. Then this enzyme solution was loaded onto the Sephadex G-100 column equilibrated with $10 \mathrm{mM}$ Na-phosphate buffer ( $\mathrm{pH}$ 8.0). In collected fractions were determined both protein amount (280 $\mathrm{nm})$ and enzyme activity $(340 \mathrm{~nm})$. The enzyme purity was controlled by SDS-PAGE method.

\section{ADH activity assay}

Alcohol dehydrogenase activity was carried out in $0.1 \mathrm{M}$ sodium phosphate at $\mathrm{pH} 7.5$ containing $0.5 \mathrm{mM} \mathrm{NAD}^{+}$and varied concentrations of ethanol as substrate. The enzyme activity was assayed by following the absorbance increase of NADH at $340 \mathrm{~nm}$, spectrophotometrically. The extinction coefficient was $6.22 \mathrm{mM}^{-1} \mathrm{~cm}^{-1}$ (Lee et al., 2015).

the $\mathrm{F}$

used

perf

1976

disce

was

Beyc

prote

elect

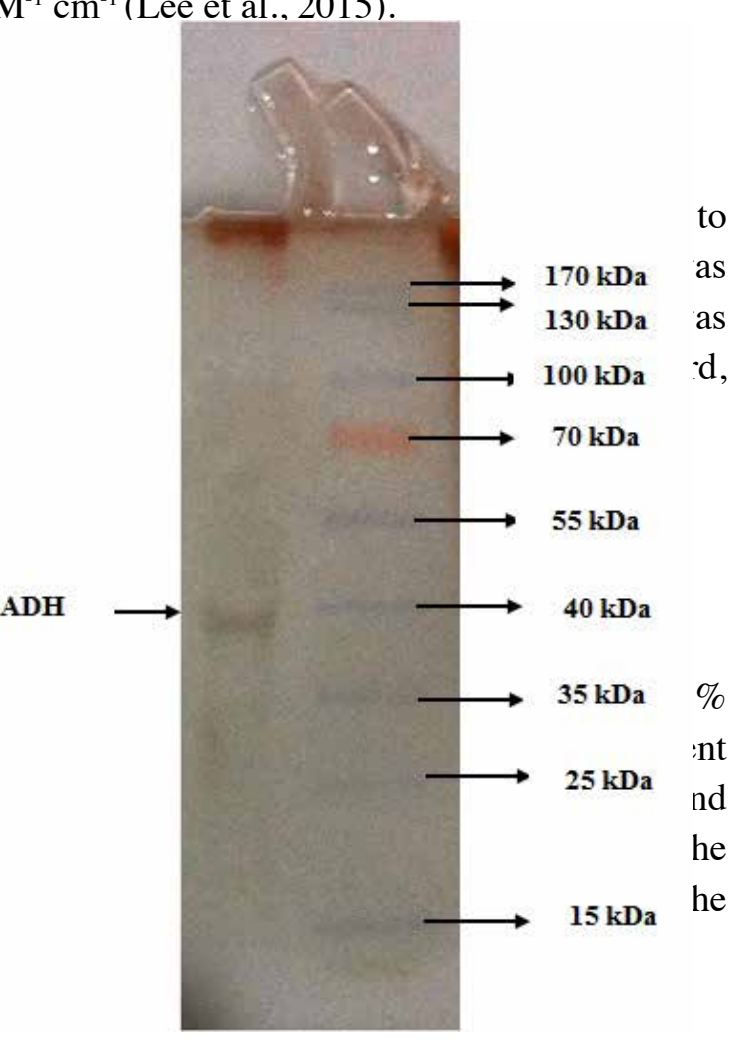

Figure 3. SDS-PAGE analysis of alcohol dehydrogenase to confirm the purify of the enzyme was carried out according to the Laemmli's method. Samples were applied as $10 \mu \mathrm{g}$ to the electrophoresis and the protein bands were obtained with siver staining. Standard protein solution contained b-Amylase, $200 \mathrm{kDa}$; Alcohol Dehydrogenase, $150 \mathrm{kDa}$; bovine serum albumin, $66 \mathrm{kDa}$; carbonic Anhydrase, $29 \mathrm{kDa}$; Cytochrome c, $12.5 \mathrm{kDa}$. 


\section{Molecular weight determination by gel filtration}

For determination of the active form molecular weight of ADH was carried out by Sephadex G100 gel (column size: $3.0 \times 40 \mathrm{~cm}$ ). Column was equilibrated using $50 \mathrm{mM}$ Tris- $\mathrm{HCl}$, pH 7.5 with $100 \mathrm{mM} \mathrm{KCl}$. Standard protein solution contained b-Amylase, $200 \mathrm{kDa}$; Alcohol Dehydrogenase, $150 \mathrm{kDa}$; bovine serum albumin, $66 \mathrm{kDa}$; carbonic Anhydrase, $29 \mathrm{kDa}$; Cytochrome c, $12.5 \mathrm{kDa}$. The standard protein fractions were eluted from the column with the same buffer. Subsequently, the pure alcohol dehydrogenase enzyme was applied to the column and was eluted. The elution volume was compared with standard proteins. Details of this technique were explained in our previous study (Yılmaz et al., 2002; Söyüt and Beydemir, 2012).

\section{Effect of pH on ADH activity}

The optimal $\mathrm{pH}$ was determined on activity of pure enzyme in the buffers at different $\mathrm{pH}$ levels (5-10.5). The prepared buffers were $0.05 \mathrm{M}$ phosphate buffer (5.0-8.0), 0.05 M Tris-HCI buffer (7.5-9.0) and $0.05 \mathrm{M}$ glycine/ $\mathrm{NaOH}$ buffer (9.0-10.5). Experiments were carried out as in our previous study (Demir and Beydemir, 2015).

\section{Effect of temperature on the alcohol dehydrogenase activity}

The measurements about the effect of temperature on the $\mathrm{ADH}$ activity were performed at various temperatures ranging from 0 to $80^{\circ} \mathrm{C}$ as in our previous study, spectrophotometrically (Demir and Beydemir, 2015).

\section{Effect of ionic strength on ADH activity}

The impact of ionic strength on ADH activity was determined using Glycine-NaOH buffer in different ionic strengths at pH 10.5. This study was carried out as in our previous studies (Demir and Beydemir, 2015).

\section{In vitro inhibition studies}

Two different group antibiotics were selected for inhibition studies. One group was aminoglycosides as kanamycin sulfate, amikacin sulfate, gentamicin, another was lincosamides as lincomycin, and clindamycin (Figure 2). $\mathrm{ADH}$ activity was assayed in five different inhibitor (I) concentrations at $340 \mathrm{~nm}$, spectrophotometrically. $\mathrm{IC}_{50}$ values of these drugs were determined from Activity\%-[I] graphs.

\section{RESULTS}

Table 1 indicates the purification results of the ADH from sheep liver with a specific activity of $0.5 \mathrm{EU} x \mathrm{mg}-1$ and approximately 52 -fold. The purification process includes simple chromatographic methods such as ammonium sulfate fractionation (60\%-80\%), DEAE-Sephadex anion exchange chromatography, and Sephadex G-100 gel filtration chromatography. The purity and of ADH was confirmed with SDS-PAGE. The subunit molecular weight was $38.16 \mathrm{kDa}$ (Table 2). Active form molecular weight of the enzyme was calculated as $80.49 \mathrm{kDa}$ by $\mathrm{K}_{\mathrm{av}}-\mathrm{Log}$ MW graph (Table 2). This experiment was carried out using Sephadex G-100 gel filtration chromatography method. Thus, dimeric form of the enzyme was revealed. The optimum $\mathrm{pH}$, ionic strength and temperature were determined as $10.5,400 \mathrm{mM}$ and $40{ }^{\circ} \mathrm{C}$, respectively (Table 2). Subsequently, in vitro inhibition effects of the antibiotics and $\mathrm{IC}_{50}$ values were calculated from Activity\%-[I] graphs (Figure 4). While kanamycin sulfate, amikacin sulfate, 
gentamicin, which are aminoglycoside had 43.31, 36.47, $20.38 \mathrm{mM}$, lincomycin, and clindamycin which are lincosamide antibiotics had 18.73 and $1.310 \mathrm{mM}$, respectively (Table 3).

Table 1. Purification steps of alcohol dehydrogenase.

\begin{tabular}{|c|c|c|c|c|c|c|}
\hline Purification steps & $\begin{array}{l}\text { Activity } \\
\left(\text { EU mL } \mathbf{L}^{-1}\right)\end{array}$ & 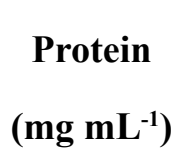 & Total & $\begin{array}{c}\text { Total } \\
\text { Activity } \\
\text { (Ë्) }\end{array}$ & $\begin{array}{c}\text { Total } \\
\text { Protein } \\
\text { (mg) }\end{array}$ & $\begin{array}{c}\text { Specific } \\
\text { Activity } \\
\left(\text { EU mg } \text { mb }^{-1}\right)\end{array}$ \\
\hline
\end{tabular}

Homogenate

$\begin{array}{llllllll}0.321 & 33.40 & 40 & 12.84 & 1336 & 0.00961 & 1 & 100\end{array}$

Ammonium

sulpate

$\begin{array}{lllllllll}\text { Precipitation (60- } & 0.279 & 30.80 & 15 & 4.185 & 462 & 0.00975 & 1.014 & 34.58\end{array}$

$80 \%)$

DEAE-Sephadex

A50 anion

exchange

0.129

9.50

$12 \quad 1.548$

$114 \quad 0.013$

1.35

12.05

chromatography

Sephadex G-100

gel filtration

chromatography

0.027

0.054

$3 \quad 0.081$

0.162

0.5

52.03

0.630

Table 2. Kinetic Properties of ADH from Sheep Liver

\begin{tabular}{|c|c|c|c|c|c|c|}
\hline Substrate & $\begin{array}{l}\text { Ionic Strength } \\
(\mathrm{mM})\end{array}$ & Optimum pH & $\begin{array}{l}\text { Optimum } \\
\left({ }^{\circ} \mathrm{C}\right)\end{array}$ & Temperature & $\begin{array}{l}\text { Subunit MW } \\
\text { (kDa) }\end{array}$ & $\begin{array}{l}\text { Natural Form MW } \\
\text { (kDa) }\end{array}$ \\
\hline Ethanol & 400 & 10.5 & 40 & & 38.16 & 80.49 \\
\hline
\end{tabular}

Table 3. $\mathrm{IC}_{50}$ and $\mathrm{R}^{2}$ Values for Sheep Liver ADH

\begin{tabular}{lcl}
\hline \multicolumn{1}{c}{ Inhibitors } & $\mathbf{I C}_{\mathbf{5 0}}(\mathbf{m M})$ & $\mathbf{R}^{\mathbf{2}}$ \\
\hline Kanamycin sulfate & 43.31 & 0.9704 \\
Amikacin sulfate & 36.47 & 0.9725 \\
Gentamicin & 20.38 & 0.9612 \\
Lincomycin & 18.73 & 0.9643 \\
Clindamycin & 1.310 & 0.9834 \\
\hline
\end{tabular}



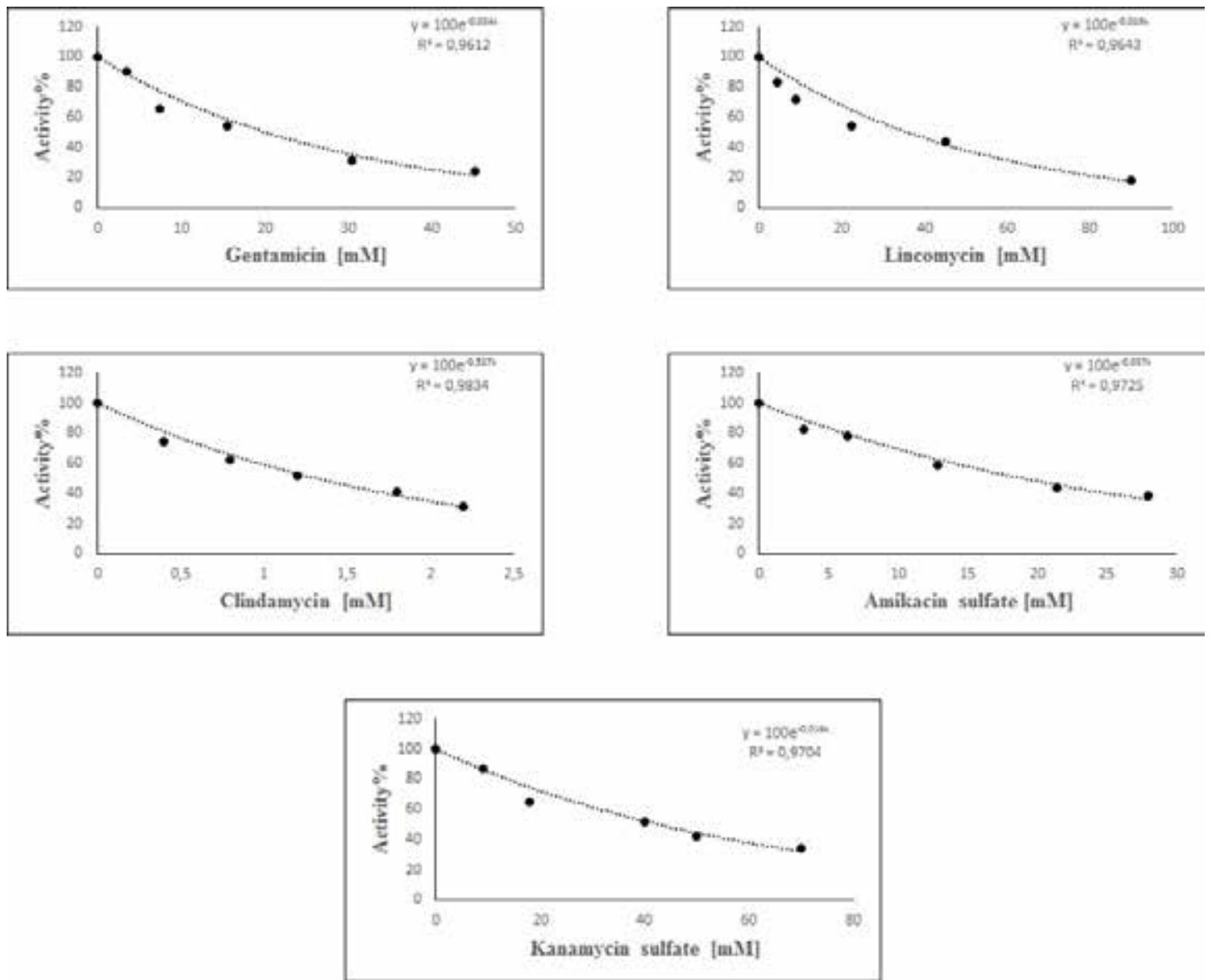

Figure 4. Inhibition graphs of kanamycin sulfate, amikacin sulfate, gentamicin, lincomycin, and clindamycin by using five different compounds concentrations for determination of $\mathrm{IC}_{50}$.

\section{DISCUSSION}

Alcohol dehydrogenase is a zinc metalloenzyme and responsible for the oxidation of alcohols to aldehydes in the liver (Raj et al., 2014). ADH has been found in many organisms such as yeast, plants, microbes, mammals. Yeast ADH has been extensively used in producing stereospecific organic molecules, medicinal compounds, industrially relevant materials and fermentation products other (Drauz, 2012; Itoh, 2014; Kirmair et al., 2015). Until now, this important enzyme has been purified from many sources such as plant, yeast, bacteria and various animal tissues. For instance, ADH was purified and characterized from Arabidopsis thaliana which is a model organism having small flowers. They used Escherichia coli system for expression and purification methods contained metal chelating affinity chromatography. Subsequently, they determined some enzymatic properties such as optimal $\mathrm{pH}$, and $\mathrm{K}_{\mathrm{m}}$ value of various alcohols as substrates. Obtained optimum
$\mathrm{pH}$ (10.5) was observed that it was different than ADHs from other sources (Cheng et al., 2013). In addition, Akduman et al (2013) were able to purify the alcohol dehydrogenase from yeast with a single-step by using their own synthesized gel. They obtained the enzyme from Baker's yeast with $48.6 \mathrm{U}$ x mg-1 specific activity and $62.7 \%$ yield. In another study, ADH enzyme was purified from Thermus thermophilus with $68 \%$ yield and 25-fold purification using a single chromatographic step (Raghava and Gupta, 2010) Purifications and characterizations of enzymes are important in order to develop strategies to be able to monitor the enzyme behavior in the solutions. For instance, $\mathrm{pH}$ is directly effective on the ionizable groups of the amino acid in the catalytic site of the enzymes. At the same way, salt concentration and temperature can largely change to the enzymatic activity. Knowing these parameters is crucial for in $v i$ tro interactions studies. In the present study, ADH was purified with 52.03-fold purification from sheep liver 
using two simple chromatographic methods including DEAE-Sephadex A-50 ion exchange chromatography and gel filtration on Sephadex G-100 (Table 1). After then, ADH was characterized in terms of some enzymatic properties such as optimum ionic strenght, temperature and $\mathrm{pH}$. They were found as $400 \mathrm{mM}, 40^{\circ} \mathrm{C}$ and, 10.5, respectively. Also, the subunit and the natural molecular weights of the enzyme were determined as 80.49 and $38.16 \mathrm{kDa}$ by gel filtration chromatography and SDS-PAGE. Thus, it was understood having a dimeric three dimensional structure of ADH as in accordance with the literature (Cheng et al., 2013; Raghava and Gupta, 2010)

In vitro and in vivo inhibition studies of the enzymes are very important to light the metabolic pathways. Moreover, the effects of drugs including various chemicals such as pesticides, herbicides, heavy metals and determining their toxicities are understood with their knowing the effect mechanisms of enzymes. Many chemicals may be effective on the various enzymes systemic or dramatically. Even, some enzymes are well known as drug-target macromolecules. For instance, carbonic anhydrases (CAs) are a large family of the metalloenzymes. CAs are found in almost all tissues and may effect from a lot of chemicals and drugs, directly (Söyüt and Beydemir, 2008; Çoban et al., 2009). For example, in our previous study was showed in vitro and in vivo effects of gentamicin sulfate on CA-I and II isozyme activity. It is interesting that they found CA inhibition in in vivo. On the other hand, CA activity is inhibited at low concentrations in vitro conditions, at high concentrations are also activated (Beydemir et al., 2002) Besides, paraoxonase, glucose-6-phosphate dehydrogenase and sorbitol dehydrogenase are enzymes studied the interactions with different chemicals (Ekinci and Beydemir, 2009; Beydemir et al., 2003; Alım and Beydemir, 2012) In the present study, gentamycin, kanamycin, amikacin, lincomycin and clindamycin were selected to investigate inhibitory effect on the alcohol dehydrogenase activity. While the gentamycin, kanamycin and amikacin were aminoglycoside drugs, lincomycin and clindamycin were lincosamide group. All of these antibacterial drugs inhibited the sheep liver ADH. The order of inhibition is as follows: clindamycin $>$ lincomycin $>$ gentamicin $>$ amikacin sulfate $>$ kanamycin sulfate. That is interesting, clindamycin and lincomycin, which is lincosamide drugs, had the most effective inhibition with the $\mathrm{IC}_{50}$ values, 1.31 and $18.73 \mathrm{mM}$, respectively. Both drugs have $-\mathrm{SH}$ group in their structure as different from the others. Moreover, clindamycin contains a chlorine $(\mathrm{Cl})$ group unlike lincomycin. We think that chlorine at the clindamycin structure may be effective in inhibition level. Because, $\mathrm{Cl}$ is known anion its inhibitory property on activities of the enzymes, generally. Also, low inhibition levels of other drugs are considered originated from their similar functional groups. There are several studies on inhibition mechanism of ADH from obtained various sources. For example, some reports showed that 2,2,2-trifluoroethanol, (Taber, 1998) thiol compound (pyrazoles) (Li et al., 2010) and 4,4' dithiodipyridine (Zheng et al., 1997) inhibited the alcohol dehydrogenase. In another study, isolated catechins, and flavonoids from the leaves of Camellia sinensis exhibited yeast alcohol dehydrogenase (ADH) inhibitory activities in the range of $\mathrm{IC}_{50}$ 8.0-70.3 $\mu \mathrm{M}$ (Manir et al., 2012). In addition, Lee et al. studied inhibition of acetaminophen on recombinant human ADH isoenzymes, recombinant human (aldehyde dehydrogenase A1) ALDH1A1 and ALDH2. They found that acetaminophen showed noncompetitive inhibition for ADH enzymes and ALDH2, but ALDH1A1 showed competitive inhibition (Lee et al., 2013).

\section{CONCLUCION}

In conclusion that ADH enzyme was purified from sheep liver by using simple chromatographic methods at three steps. The characterization of the enzymatic properties was carried out for determining $\mathrm{pH}$, ionic strength, temperature, subunit molecular weight and active form molecular weight. After then, in vitro inhibition studies of kanamycin sulfate, amikacin sulfate, gentamicin, lincomycin, and clindamycin were performed on ADH activity. The drugs were potential inhibitors for ADH. Particularly, lincosamide drugs were most effective on the enzyme activity. We consider that this study will be help adjusting of drug dosages at the therapy. Besides, this study may give ideas about developing of new inhibitors of alcohol dehydrogenase enzyme. 


\section{REFERENCES}

Akduman B, Uygun M, Aktaş Uygun D, Akgöl S, Denizli A, 2013. Purification of yeast alcohol dehydrogenase by using immobilized metal affinity cryogels. Materials Science and Engineering, C 33; 4842-4848.

Alım Z, Beydemir S, 2016. Some Anticancer Agents Act on Human Serum Paraoxonase-1 to Reduce Its Activity. Chem Biol Drug Des, 88 (2); 188-96.

Alım Z, Beydemir Ş, 2012. Effects of some anti-neoplastic drugs on sheep liver sorbitol dehydrogenase. Arch. Physiol. and Biochem., 118; 244-252.

Aslan HE, Beydemir Ş, 2017. Phenolic compounds: The inhibition effect on polyol pathway enzymes. Chemico-Biological Interactions, 266; 47-55.

Batzias GC, Delis GA, Athanasiou, LV, 2005. Clindamycin bioavailability and pharmacokinetics following oral administration of clindamycin hydrochloride capsules in dogs. Vet .J., 170 (3); 339-45.

Beydemir Ş, Çiftçi M, Küfrevioğlu Öİ, Büyükokuroğlu ME, 2002. Effects of gentamicine sulfate on enzyme activities of carbonic anhydrase from human erythrocytes in vitro and from rat erythrocytes in vivo. Biol. Pharm. Bull., 25; 966-969.

Beydemir Ş, Kulaçoğlu DN, Çiftçi M, Küfrevioğlu Öİ, 2003. The effects of some antibiotics on sheep lens glucose 6-phosphate dehydrogenase in vitro. Eur. J. Ophthalmol., 13; 155-161.

Bradford MM, 1976. Rapid and Sensitive Method for Quantitation of Microgram Quantities of Protein Utilizing Principle of ProteinDye Binding. Analytical Biochemistry, 72 (1-2); 248-254.

Cheng F, Hu, T, An Y, Huang J, Xu Y, 2013. Purification and enzymatic characterization of alcohol dehydrogenase from Arabidopsis thaliana. Protein Expression and Purification, 90; 74-77.

Çoban TA, Beydemir Ş, Gucin I, Ekinci D, Innocenti A, Vullo D, Supuran CT, 2009. Sildenafil is a strong activator of mammalian carbonic anhydrase isoforms I-XIV. Bioorgan. Med. Chem., 17; 5791-5795.

Demir Y, Beydemir S, 2015. Purification, refolding, and characterization of recombinant human paraoxonase-1. Turkish Journal of Chemistry, 39 (4); 764-776.

Drauz K, 2012. Enzyme catalysis in organic synthesis: a comprehensive handbook. John Wiley \& Sons.

Ekinci D, Beydemir Ş., 2009. Effect of some analgesics on paraoxonase-1 purified from human serum. Journal of Enzyme Inhibition and Medicinal Chemistry, 24 (4); 1034-1039.

Giguère S, 2013. Lincosamides, Pleuromutilins, and Streptogramins Antimicrobial Therapy in Veterinary Medicine. John Wiley \& Sons, Inc.

İsgör MM, Beydemir S, 2010. Some cardiovascular therapeutics inhibit paraoxonase 1 (PON1) from human serum. Eur $\mathbf{J}$ Pharmacol, 645 (1-3); 135-42.

Itoh N, 2014. Use of the anti-Prelog stereospecific alcohol dehydrogenase from Leifsonia and Pseudomonas for producing chiral alcohols. Applied Microbiology and Biotechnology, 98 (9); 3889-3904.
Kent A, Turner MA, Sharland M, Heath PT, 2014. Aminoglycoside toxicity in neonates: something to worry about? Expert Rev Anti Infect Ther, 12 (3); 319-31.

Kirmair L, Seiler DL, Skerra A, 2015. Stability engineering of the Geobacillus stearothermophilus alcohol dehydrogenase and application for the synthesis of a polyamide 12 precursor. Appl Microbiol Biotechnol, 99 (24); 10501-13.

Kotra LP, Haddad J, Mobashery S, 2000. Aminoglycosides: perspectives on mechanisms of action and resistance and strategies to counter resistance. Antimicrob Agents Chemother, 44 (12); 3249-56.

Laemmli UK, 1970. Cleavage of Structural Proteins during Assembly of Head of Bacteriophage-T4. Nature, 227(5259); 680 .

Lee SL, Lee YP, Wu ML, Chi YC, Liu CM, Lai CL, Yin SJ, 2015. Inhibition of human alcohol and aldehyde dehydrogenases by aspirin and salicylate: Assessment of the effects on first-pass metabolism of ethanol. Biochemical Pharmacology, 95 (1); 71-79.

Lee YP, Liao JT, Cheng YW, Wu TL, Lee SL, Liu JK, Yin SJ, 2013. Inhibition of human alcohol and aldehyde dehydrogenases by acetaminophen: Assessment of the effects on first-pass metabolism of ethanol. Alcohol, 47 (7); 559-565.

Li J, Jiang Z, Wu H, Liang Y, Zhang Y, Liu J, 2010. Enzymepolysaccharide interaction and its influence on enzyme activity and stability. Carbohydr. Polym., 82; 160-166.

Li Y, Ding WX, 2017. Adipose tissue autophagy and homeostasis in alcohol-induced liver injury. Liver Research, 1-9. https://doi. org/10.1016/j.livres.2017.03.004

Lin L, Wagner MC, Cocklin R, Kuzma A, Harrington M, Molitoris BA, Goebl MG, 2011. The Antibiotic Gentamicin Inhibits Specific Protein Trafficking Functions of the Arf1/2 Family of GTPases. Antimicrobial Agents and Chemotherapy, 55 (1); 246-254

Manir MM, Kim, JK, Lee BG, Moon SS, 2012. Tea catechins and flavonoids from the leaves of Camellia sinensis inhibit yeast alcohol dehydrogenase. Bioorg. Med. Chem., 20(7); 2376-81.

Mert S, Alım Z, İşgör MM, Beydemir Ş, Kasımoğulları R, 2016. The synthesis of novel pyrazole-3,4-dicarboxamides bearing 5-amino-1,3,4-thiadiazole-2-sulfonamide moiety with effective inhibitory activityagainst the isoforms of human cytosolic carbonic anhydrase I and II. Bioorganic Chemistry, $68 ; 64-71$

Raghava S, Gupta MN, 2010. Purification and characterization of an alcohol dehydrogenase with an unusual specificity towards glycerol from Thermus thermophiles. Bioresource Technology, 101; 2554-2557.

Raj SB, Ramaswamy S, Plapp BV, 2014. Yeast alcohol dehydrogenase structure and catalysis. Biochemistry, 53 (36); 5791-803.

Söyüt H, Beydemir Ş, 2008. Purification and some kinetic properties of carbonic anhydrase from rainbow trout (Oncorhynchus mykiss) liver and metal inhibition. Protein and Peptide Letters, 15 ; 528-535. 
Söyüt H, Beydemir Ş, 2012. The impact of heavy metals on the activity of carbonic anhydrase from rainbow trout (Oncorhynchus mykiss) kidney. Toxicol. Ind. Health., 28, 296-305.

Stickel F, Moreno C, Hampe J, Morgan MY, 2017. The genetics of alcohol dependence and alcohol-related liver disease. Journal of Hepatology, 66; 195-211.

Sunderland JR, Tao X, Butrick EE, Keilich LC, Villa CE, Miecznikowski JR, Jain SS, 2016. Investigation of liver alcohol dehydrogenase catalysis using an NADH biomimetic and comparison with a synthetic zinc model complex. Polyhedron, 114; 145-151.

Taber RL, 1998. The competitive inhibition of yeast alcohol dehydrogenase by 2,2,2-trifluoroethanol. Biochemical Education, 26 (3); 239-242.
Türkeş C, Söyüt H, Beydemir Ş, 2016. In vitro inhibitory effects of palonosetron hydrochloride, bevacizumab and cyclophosphamide on purified paraoxonase-I (hPON1) from human serum. Environmental toxicology and pharmacology, $42 ; 252-257$.

Yllmaz H, Ciftci M, Beydemir S, Bakan E, 2002. Purification of glucose 6-phosphate dehydrogenase from chicken erythrocytes. Investigation of some kinetic properties. Preparative Biochemistry and Biotechnology, 32; 287-301

Zheng SY, Xu D, Wang HR, Li J, Zhou HM, 1997. Kinetics of irreversible inhibition of yeast alcohol dehydrogenase during modification by 4,4'-dithiodipyridine. International Journal of Biological Macromolecules, 20 (4); 307-313. 